\title{
Dårlig prognose ved hjerneinfarkt i ung alder
}

\author{
Hjerneinfarkt i ung alder antas ofte å ha god prognose, men få langtidsresultater foreligger. I Hordaland \\ har vi fulgt en gruppe unge pasienter med hjerneinfarkt i ca. 12 år. Funnene fra denne studien har fått \\ konsekvenser.
}

Gjennomsnittsalderen for hjerneslag i Skandinavia er 75 år. Alder er den dominerende risikofaktoren for hjerneslag, og søkelyset er derfor oftest rettet mot eldre pasienter. Imidlertid har redusert fysisk og kognitiv funksjon hos unge pasienter under utdanning, med ansvar for mindreårige barn og i yrker med ansvarsfulle posisjoner, store og langvarige sosiale konsekvenser for den enkelte, i tillegg til store sosioøkonomiske konsekvenser for familien og samfunnet.

Vi mener derfor at det bør satses sterkere på gode og gjentatte folkehelseopplysningskampanjer om risikofaktorer for vaskulær sykdom, slagsymptomer og preventiv behandling - også rettet mot yngre målgrupper.

\section{Studien i Hordaland}

Vår forskningsgruppe fulgte over 12 år 232 pasienter med første gangs hjerneinfarkt $i$ alderen 15-49 år. Pasientene ble rekruttert retrospektivt i perioden 1988-1997 fra de fem sykehusene i Hordaland: Haukeland universitetssykehus, Haraldsplass Diakonale sykehus, Voss, Odda og Stord sykehus.

Gjennomsnittsalderen ved hjerneinfarktet var 41 år. Hver pasient ble sammenliknet med to kontrollpersoner via folkeregisteret (1). Oppfølging ble utført etter 6 og 12 års gjennomsnittlig observasjonstid, og en siste overlevelsesundersøkelse ble utført i 2012, etter 18 år.

Selvoppgitt informasjon angående kardiovaskulære risikofaktorer, tidligere sykehistorie, søvn- og hukommelsesproblemer, depresjon og angstplager ble innhentet via et standardisert spørreskjema og sammenliknet for pasienter og kontrollpersoner. Ved første oppfølging ble pasientene undersøkt klinisk, med EKG og blodtrykksmåling. Ved andre oppfølging ble pasientene i tillegg undersøkt med duplekssonografi av karotidene for måling av intima-media-tykkelse og plakkforekomst i tre carotissegmenter (2).

\section{Nedslående resultater}

Våre funn er nedslående for prognosen hos unge pasienter med hjerneinfarkt. Disse pasientene hadde ti ganger økt dødelighet, fem ganger økt forekomst av nye arterielle hendelser og åtte ganger økt forekomst av hukommelsesproblemer - sammenliknet med jevnaldrende kontrollpersoner.

Ved første oppfølging hadde $10 \%$ gjennomgått residivslag (1). Nye kardiovaskulære hendelser varierte med antall risikofaktorer, fra $2 \%$ hos pasienter med null risikofaktorer til $67 \%$ hos dem med fem risikofaktorer $(3,4)$. Antall risikofaktorer var dermed vesentlig for den videre prognosen. Ved andre oppfølging var mortaliteten hos pasientene ti ganger høyere enn hos kontrollpersonene (19\% versus $2 \%$ ) (5).

Av 144 pasienter som ble undersøkt etter gjennomsnittlig 12 års observasjonstid, fungerte $91 \%$ selvstendig i det daglige. Pasientene hadde imidlertid fem ganger høyere forekomst av arterielle hendelser sammenliknet med kontrollpersonene $(5,6)$, og $75 \%$ av

\section{«Hos pasientene med hjerneslag var hukom- melsesproblemer åtte ganger vanligere»}

pasientene hadde patologisk intima-mediafortykkelse i carotisarteriene (2). Blodtrykk $>140 / 90 \mathrm{~mm} \mathrm{Hg}$ ble funnet hos $66 \%$ av pasientene, og $66 \%$ brukte ikke statiner. Halvparten av pasientene som røykte da de fikk hjerneinfarkt, røykte fremdeles (7).

Hos pasientene med hjerneslag var hukommelsesproblemer åtte ganger vanligere, epilepsi var ti ganger vanligere, og dobbelt så mange pasienter hadde angst, depresjon og søvnproblemer som kontrollpersonene (7). Det var ingen signifikant forskjell angående heltidsarbeid mellom pasienter med hjerneslag uten hukommelsesproblemer og kontrollpersoner (7). Pasienter med hukommelsesproblemer mottok uføretrygd tre ganger hyppigere enn pasienter uten hukommelsesproblemer (7).

Den siste mortalitetsanalysen for pasienter ble utført i 2012. Den eldste var da 72 år gammel. Av opprinnelig 232 pasienter var $63(27 \%)$ døde. Mortalitet økte fra $13 \%$ for pasienter uten registrerte risikofaktorer ved studieinklusjon til 19\% hos dem med én risikofaktor, $25 \%$ med to risikofaktorer og $53 \%$ med tre eller flere risikofaktorer (8).

\section{Risikofaktorer og residivslag}

Våre data viser at hjerneinfarkt $i$ ung alder ikke har god prognose. Pasientene har høy mortalitet, hovedsakelig grunnet progredierende kardiovaskulær sykdom. Til tross for selvstendig funksjon i det daglige etter infarktet hos ni av ti pasienter $(9,10)$, har nyere studier fra Spania og Finland også vist dårlig langtidsprognose angående mortalitet og nye kardiovaskulære hendelser $(10,11)$. Hjerneinfarkt kan føre til kognitiv reduksjon og utvikling av demens, og slik risiko øker med residivslag (12). En finsk studie fant at kun $13 \%$ av 990 unge pasienter med hjerneinfarkt i alderen 15-49 år ikke hadde risikofaktorer (13).

Resultatene fra denne studien har ført til konkrete tiltak rettet mot unge pasienter med hjerneinfarkt på Nevrologisk avdeling ved Haukeland universitetssykehus. Alle pasienter kartlegges nå med standardiserte spørreark for å identifisere risikofaktorer, og det er etablert et standardisert og utvidet undersøkelsesprogram for de unge pasientene. Med utgangspunkt i resultatene fra de unge pasientene med hjerneinfarkt i Hordaland har vi startet «The Norwegian Stroke in the Young Study (NOR-SYS)», planlagt som en nasjonal multisenterstudie.

Standardisert, omfattende utredning og kartlegging av risikofaktorer for klinisk og subklinisk kardiovaskulær sykdom hos unge pasienter med hjerneinfarkt er nødvendig for å kunne identifisere og behandle modifiserbare risikofaktorer aggressivt. Slik kan risikoen for residivslag, kognitive problemer, demens og tidlig død reduseres hos disse pasientene.

\section{Ulrike Waje-Andreassen \\ uwan@helse-bergen.no \\ Lars Thomassen \\ Halvor Næss}

Ulrike Waje-Andreassen (f. 1962) er spesialist i nevrologi, ph.d. og overlege ved Senter for nevrovaskulære sykdommer, Nevrologisk avdeling, Haukeland universitetssykehus. Forfatter har fylt ut ICMJE-skjemaet og oppgir følgende interessekonflikter: Studien er innvilget støtte fra Helse Vest, Frank Mohns stiftelse, Bergen. Hun har mottatt foredragshonorar fra Boehringer Ingelheim om «Young Stroke».

Lars Thomassen (f. 1947) er spesialist i nevrologi, overlege ved Senter for nevrovaskulære sykdommer, Nevrologisk avdeling. Haukeland universitetssykehus og professor ved Institutt for klinisk medisin, Universitetet i Bergen.

Forfatter har fylt ut ICMJE-skjemaet og oppgir ingen interessekonflikter. 
Halvor Næss (f. 1957) er spesialist i nevrologi og i indremedisin, dr. med. og overlege ved Senter for nevrovaskulære sykdommer, Nevrologisk avdeling, Haukeland universitetssykehus og professor ved Institutt for klinisk medisin, Universitetet i Bergen.

Forfatter har fylt ut ICMJE-skjemaet og oppgir ingen interessekonflikter.

\section{Litteratur}

1. Næss H, Nyland HI, Thomassen L et al. Long-term outcome of cerebral infarction in young adults. Acta Neurol Scand 2004; 110: 107-12.

2. Waje-Andreassen $U$, Næss $H$, Thomassen $L$ et al. Ultrasound, atherosclerosis and stroke at a young age: a cross-sectional long-term follow-up in western Norway. Eur J Neurol 2008; 15: 512-9.

3. Næss H, Nyland HI, Thomassen L et al. Etiology of and risk factors for cerebral infarction in young adults in western Norway: a population-based case-control study. Eur J Neurol 2004; 11: 25-30.

4. Næss $H$, Waje-Andreassen $U$, Thomassen $L$ et al. Do all young ischemic stroke patients need longterm secondary preventive medication? Neurology 2005; 65: 609-11.

5. Waje-Andreassen $U, N æ s s ~ H$, Thomassen $L$ et al. Long-term mortality among young ischemic stroke patients in western Norway. Acta Neurol Scand 2007; 116: 150-6.

6. Waje-Andreassen U, Næss H, Thomassen L et al. Arterial events after ischemic stroke at a young age: a cross-sectional long-term follow-up of patients and controls in western Norway. Cerebrovasc Dis 2007; 24: 277-82.

7. Waje-Andreassen $U$, Thomassen L, Jusufovic M et al. Ischaemic stroke at a young age is a serious event-final results of a population-based longterm follow-up in Western Norway. Eur J Neurol 2013; 20: 818-23.

8. Næss H, Waje-Andreassen U, Nyland H. Risk factor burden predicts long-term mortality in young patients with arterial cerebral infarction. Acta Neurol Scand 2013; 127: 92-6.

9. Leys D, Bandu L, Hénon H et al. Clinical outcome in 287 consecutive young adults (15 to 45 years) with ischemic stroke. Neurology 2002; 59: 26-33.

10. Varona JF, Bermejo F, Guerra JM et al. Long-term prognosis of ischemic stroke in young adults. Study of 272 cases. J Neurol 2004; 251: 1507-14.

11. Putaala J, Haapaniemi E, Metso AJ et al. Recurrent ischemic events in young adults after firstever ischemic stroke. Ann Neurol 2010; 68: $661-71$.

12. Gottesman RF, Hillis AE. Predictors and assessment of cognitive dysfunction resulting from ischaemic stroke. Lancet Neurol 2010: 9: 895-905.

13. Putaala J, Haapaniemi E, Kaste M et al. How does number of risk factors affect prognosis in young patients with ischemic stroke? Stroke 2012; 43: 356-61.

Mottatt 29.4. 2013, første revisjon innsendt 5.6. 2013, godkjent 17.6. 2013. Medisinsk redaktør Hanne Støre Valeur.

Publisert først på nett. 